\title{
Visit Intention and Destination Image in Post- Covid-19 Crisis Recovery
}

\author{
Albattat Ahmad \\ Postgraduate Centre, Management and Science University, University Drive, Off Persiaran Olahraga, \\ Section 13, 40100, Selangor, Malaysia \\ Postgraduate Program (Master program), Medan Polytechnic of Tourism, Rumah Sakit Haji, Street \\ No. 12, Medan, 20371, North Sumatera, Indonesia
}

Azizul Jamaludin

School of Hospitality and Creative Arts, Management and Science University, University Drive, Off Persiaran Olahraga, Section 13, 40100, Selangor, Malaysia

Nini Shaliza

School of Hospitality and Creative Arts, Management and Science University, University Drive, Off Persiaran Olahraga, Section 13, 40100, Selangor, Malaysia

Mohd Zuraimi

School of Hospitality and Creative Arts, Management and Science University, University Drive, Off Persiaran Olahraga, Section 13, 40100, Selangor, Malaysia

Marco Valeri

NCI University London, Selsdon Way Northern \& Shell London E14 9GL Faculty of Economics, Niccolò Cusano University Don Gnocchi Street, 00166 Rome

\begin{abstract}
The aim of this research is to analyze the factors influencing visit intention and destination image in postCovid-19 crisis recovery. In post-crisis recovery, the factors influencing visit intention are physical, socio-psychological and financial factors. A total of 426 respondents were selected and analyzed using correlation and multiple regression analyses. The findings demonstrate that physical factors are the main factors that influence tourists' visit intention. Additionally, destination image significantly affects visit intention and significantly mediates the relationship between the factors and visit intention. All this inevitably affects the organizational structure of the tourist destination.
\end{abstract}

Keywords - Asian and European, Destination crisis management, Destination image, Travel motivation, Visit intention.

SUGGESTED CITATION: Ahmad, A., Jamaludin, A., Shaliza, N., Zuraimi, M., \& Valeri, M. (2021). Visit Intention and Destination Image in Post-Covid-19 Crisis Recovery. Proceedings of the International Crisis and Risk Communication Conference, Volume 4 (pp. 16-18). Orlando Fl: Nicholson School of Communication and Media. https://doi.org/10.30658/icrcc.2021.04

\section{INTRODUCTION AND FRAMEWORK}

Traveller inspiration can be characterized as the worldwide coordinated system of natural and social powers that provides worth and guidance for travel decisions, conduct, and experience [1]. Travel inspiration has reliably been a basic factor in the tourism business [2]. Travel motivation is related to many necessities that make a traveller decide to participate in the ISSN: 2576-9111

(C) 2021 Copyright is held by the owner/author(s).

Publication rights are licensed to ICRCC.

https://doi.org/10.30658/icrcc.2021.04 
tourism industry. Travel inspiration is uncertain and subject to change because of envisioned and inconsistent internal and external events such as emergencies, catastrophes [3]. Ajzen said, according on the theory of planned behavior, travellers' expectations depend on internal or external variables that impact their movement inspiration when visiting [4]. Malaysia's tourism industry has experienced difficulty owing to a decline in traveller appearances, especially in Asian and European tourists, from 2014 to 2019. Analysis shows that traveller appearances initially decreased from 26.76 million in 2016 to 25.95 million in 2017 and then continued to fall to 25.83 million in 2019. Travellers from European nations decreased from 1 million in 2015 to 987.2 thousand in 2017 and then increased to 1 million in 2018. The decrease in visitors could be due to the two Malaysia Airlines crashes in 2014, Malaysia being blacklisted by China, the kidnapping at Sabah, and the Covid-19 pandemic, all of which were crises that caused uncertainty in travellers visiting Malaysia. Crises are one of the important issues that must be avoided in the travel industry $[5,6,7,8]$.

\section{METHODOLOGY}

Quantitative research in this area has centred around factual examinations of numerical information gathered by utilizing an overview on an enormous scale [9, 10]. In this research, the populations were Asian and European vacationers visiting Kuala Lumpur, and the aim was to study the effect of physical, socio-psychological, and financial factors on visit intention mediated by destination image. The researcher's sample criteria were Asian and European visitors between the ages of 18 and 65 years visiting Malaysia in March 2020. The number of surveys gathered totalled 480, of which 426 were valid for analysis, for a $0.80 \%$ response rate.

\section{DESCRIPTIVE ANALYSIS OF RESPONDENTS}

The majority of the respondents were male, representing $50.7 \%(\mathrm{~N}=216) ; 49.3 \%(\mathrm{~N}=210)$ were female; $42.0 \%(\mathrm{~N}$ $=179)$ were Asian; and 58.0\% $(\mathrm{N}=247)$ were European. Nearly half $(43.3 \%)$ of the respondents were $21-30$ years old $(\mathrm{N}=193)$, and $30.8 \%(\mathrm{~N}=131)$ of the respondents had a monthly income of $<$ USD 500 . Travellers from Europe like to visit ecotourism areas. Of the respondents, 59.2\% had obtained the majority of their information about Malaysia from the website $(\mathrm{N}=252)$, which shows that the travel industry site provided a decent translation. Of the respondents, $57.3 \%$ were travelling independently $(\mathrm{N}=244)$.

\section{DESCRIPTIVE STATISTICS}

The descriptive statistics of the items are travel motivation, intention to visit and mediating variable. The physical factor variable section shows that adequate accommodation had the highest median at 3.98, followed by climate at 3.58 . The socio-psychological variable section shows that most of the respondents visited Malaysia because of the attractiveness of its culture and history, with a median of 4.01. This finding indicates that Malaysia has maintained its original identity.

\section{RESULTS}

\section{CORRELATION TESTING}

The analysis indicates that all the relationships were supported, but with different strengths, which shows that Asian and European tourists agreed that the socio-psychological factors had the strongest influence, with a moderate strength coefficient value of $\beta=.588$ for destination image in hypothesis 1 , while the factor with the weakest influence was the relationship between the financial factor and destination image, with a moderate strength coefficient value of $\beta=.490$ in hypothesis 3 . However, the relationship between destination image and intention to visit was positive, showing that this relationship contributes strongly to tourists' visit intention, with a coefficient value of $\beta=.765$ in hypothesis 4 . Therefore, physical factors had the highest value, with a moderate strength coefficient value of $\beta=.515$ regarding the relationship of these physical factors and Asian and European tourists' visit intention in hypothesis 5, while financial factors had the lowest value at only $\beta=.343$, which shows that financial factors have weak relationships with the visit intention factors in hypothesis 7.

\section{MULTIPLE REGRESSION TESTING}

Results shows that destination image is positively affected as a mediating factor in the relationships among the physical, socio-psychological, and financial factors that influence visit intention during post-crisis recovery. Hypothesis 8 states that destination image mediates the relationship between physical factors and intention to visit, with a positive strength coefficient value of $\beta=11.485$, followed by socio-psychological factors, with a positive strength coefficient value of $\beta=11.159$ in hypothesis 9 , and financial factors, with a positive strength coefficient value of $\beta=15.436$ in hypothesis 10 .

\section{DISSCUSSION}

There is a positive relationship between destination image and visit intention that contributes strongly to tourist visit 
intention, with a coefficient value of $\beta=.765$. Physical factors had a moderate relationship with Asian and European tourists' visit intention because, as the analysis shows, many tourists agreed that Malaysia supplies good services and hospitality products to customers, which had a positive effect, indirectly leading to tourists intending to visit Malaysia. This finding is compared to the second type of factor - socio-psychological factors - with moderate strength and a coefficient value of $\beta=.514$, while financial factors had the lowest value at only $\beta=.343$, showing that financial factors have a weak relationship with visit intention factors. The analysis in this section overall supports hypotheses five, six and seven and agrees with the findings of Quintal \& Polczynski and Tavitiyaman \& Qu.

\section{CONCLUSION AND LIMITATIONS}

In this research, Malaysia was a leader in emergency recuperation in terms of the factors impacting Asian and European travellers' visit expectations, with a spotlight on the factors incorporated into destination image in relation to intention to visit. The way in which Malaysia enforced a movement control order during the Covid-19 pandemic showed that a crisis management plan helps identify potential threats and prepare important responses. This study has limitations. The research was conducted with the use of a large amount of past research and much data about how post-emergency components impact travellers' intention to visit Malaysia, which can assist different analysts in understanding all of the factors involved. Future research could further investigate the effects of the Covid19 disaster on the tourism industry and the effects on sustainable tourism performance.

\section{Author Biography}

Albattat Ahmad PhD (MSU), Postgraduate Centre, Management and Science University, dr.battat@msu.edu.my.

\section{REFERENCES}

[1] Björk, P., \& Kauppinen-Räisänen, H. (2019). Destination foodscape: A stage for travelers' food experience. Tourism Management, 71, 466-475. https://doi.org/10.1016/j.tourman.2018.11.005

[2] Elmo, G. M., Arcese, G., Valeri, M., Poponi, S., \& Pacchera, F. (2020). Sustainability in tourism as an innovation driver: An analysis of family business Reality. Sustainability, 12(15), 6149. https://doi.org/10.3390/su12156149

[3] Chemli, S., Toanoglou, M., \& Valeri, M. (2020). The impact of Covid-19 media coverage on tourist's awareness for future traveling. Current Issues in Tourism. https://doi.org/10.1080/13683500.2020.1846502

[4] Sigala, M. (2020). Tourism and COVID-19: Impacts and implications for advancing and resetting industry and research. Journal of Business Research, 117, 312-321. https://doi.org/10.1016/j.jbusres.2020.06.015

[5] Baggio, R., \& Valeri, M. (2020). Network science and sustainable performance of family businesses in tourism. Journal of Family Business Management. https://doi.org/10.1108/JFBM-06-2020-0048

[6] Foo, L., Chin, M., Tan, K., \& Phuah, K. (2020). The impact of COVID-19 on tourism industry in Malaysia. Current Issues In Tourism, 1-5. https://doi.org/10.1080/13683500.2020.1777951

[7] Som, A. P. M., Aun, O. C., \& AlBattat, A. R. (2015). Tourists' perception of crisis and the impact of instability on destination safety in Sabah, Malaysia. Tourism \& Environment, Social and Management Sciences, 5, 96-103. https://doi.org/10.5829/idosi.aejaes.2015.15.s.213

[8] Valeri, M., \& Baggio, R. (2020a). Italian tourism intermediaries: A social network analysis exploration. Current Issues in Tourism, 1-14. https://doi.org/10.1080/13683500.2020.1777950

[9] Mariani, M., \& Baggio, R. (2020). The relevance of mixed methods for network analysis in tourism and hospitality research. International Journal of Contemporary Hospitality Management, 32(4), 1643-1673. https://doi.org/10.1108/IJCHM-04-2019-0378

[10] Valeri, M., \& Baggio, R. (2020b). Social network analysis: Organizational implications in tourism management. International Journal of Organizational Analysis, 29, 342-353. https://doi.org/10.1108/IJOA-12-2019-1971 